\title{
Reduction of Sulfur Dioxide to Sulfur Monoxide by Ferrous Porphyrin
}

\author{
Aishik Bhattacharya, ${ }^{\ddagger}$ Arnab Kumar Nath, ${ }^{\ddagger}$ Arnab Ghatak, ${ }^{\ddagger}$ Abhijit Nayek, Rajat Saha, Somdatta \\ Ghosh Dey*, Abhishek Dey*
}

School of Chemical Sciences, Indian Association for the Cultivation of Science, 2A Raja SC Mullick Road, Kolkata, India KEYWORDS: Sulfur Dioxide Reduction, Sulfur monoxide, Iron Porphyrin, EPR, resonance Raman.

\begin{abstract}
Reduction of $\mathrm{SO}_{2}$ to fixed forms of sulfur can address the growing concerns regarding its detrimental effect on health and environment as well as enable its valorization into valuable chemicals. While the coordination of $\mathrm{SO}_{2}$ to transition metals are documented, its reduction using molecular catalysts has remained elusive. Alternatively, the naturally occurring heme enzyme sulfite reductase is known to reduce $\mathrm{SO}_{2}$ to $\mathrm{H}_{2} \mathrm{~S}$ and is an integral part of the global sulfur cycle. However, its action is not yet mimicked in artificial systems outside of the protein matrix even after several decades of its structural elucidation. Here reduction of $\mathrm{SO}_{2}$ by iron (II) porphyrin, a synthetic analogue of heme, is demonstrated. A combination of spectroscopic and analytical methods indicates that $\mathrm{SO}_{2}$ is reduced by $2 \mathrm{e}^{-} / 2 \mathrm{H}^{+}$by Fe $\mathrm{Fe}^{\mathrm{II}} \mathrm{TPP}$ to form an intermediate [Fe $\left.{ }^{\mathrm{III}}-\mathrm{SO}\right]^{+}$species which releases SO. The SO obtained from the chemical reduction of $\mathrm{SO}_{2}$ could be valorized in the form of a Diels-Alder adduct of butadiene resulting in an organic sulfoxide.
\end{abstract}

Sulfur Dioxide $\left(\mathrm{SO}_{2}\right)$ is an atmospheric pollutant that is emitted from fossil fuel burning and smelters. An estimated $>100 \mathrm{Tg}$ of $\mathrm{SO}_{2}$ is emitted annually; mostly from human activities..$^{1-4}$ Apart from direct effects, $\mathrm{SO}_{2}$ gets oxidized in the atmosphere to sulphates which is the major component of particulate matter (PM2.5) that is detrimental for human health. ${ }^{5-6} \mathrm{~A}$ concerted global effort has led to reduction in $\mathrm{SO}_{2}$ emission in some countries, but it has been increasing substantially in developing nations which largely relies on coal for power generation. ${ }^{1}$ Fixation of $\mathrm{SO}_{2}$ by reducing it to sulfur or sulfides is an attractive approach to eliminate this pollutant and generate valuable stock chemicals. ${ }^{7}$ Most of these approaches require $\mathrm{H}_{2} / \mathrm{CO}$ gas, high temperatures and supporting metal oxide heterogeneous catalysts. ${ }^{8-11}$ Although there are some examples of transition metal complexes with bound $\mathrm{SO}_{2}$ and $\mathrm{SO},{ }^{12-17}$ reduction of $\mathrm{SO}_{2}$ by molecular systems are rare and needs to be explored to marshal newer methods for $\mathrm{SO}_{\mathrm{x}}$ valorization. ${ }^{18}$

A host of microbial organisms recycle $\mathrm{SO}_{\mathrm{x}}$ as a part of the geochemical Sulfur cycle and, recently, these organisms have been used to valorize sulfur from alkaline extract of flue gas which contains $\mathrm{SO}_{2} \cdot{ }^{19}$ The enzyme responsible for the $6 \mathrm{e}^{-} / 6 \mathrm{H}^{+}$reduction of $\mathrm{SO}_{2}$ to $\mathrm{H}_{2} \mathrm{~S}$ in these bacteria is sulfite reductase (SiR). The SiRs feature a siroheme cofactor (Figure 1) which is a member of the isobacteriochlorin family of heme cofactors..$^{20}$ The reduction of $\mathrm{SO}_{2}$ with the reduced ferrous siroheme active site of SiR has been investigated in detail using a combination of spectroscopic and theoretical techniques. ${ }^{21-23}$ A series of Iron-Sulfur clusters provide the $6 \mathrm{e}^{-}$needed for this reaction which funnel through the proximal $\mathrm{Fe}_{4} \mathrm{~S}_{4}$ cluster that bridge with the siroheme cofactor (Figure 2). The protons are provided by several arginine residues that are present in the distal cavity of the siroheme (Figure 1) cofactor. The proposed mechanism of action for this overall $6 \mathrm{H}^{+} / 6 \mathrm{e}^{-}$reduction of sulfite to sulfide by $\mathrm{SiR}$ is debatable. Using X-ray structure of $\mathrm{SO}_{3}{ }^{2-}$ bound active site and structures of other small molecules and anions bound $\mathrm{SiR}$ (e.g. $\mathrm{NO}_{2}-\mathrm{NO}, \mathrm{CO}, \mathrm{CN}^{-}$), involvement of three consecutive $2 \mathrm{H}^{+} / 2 \mathrm{e}^{-}$reduction steps which are all accompanied by water elimination (Figure 2) was proposed. ${ }^{24}$ The binding of $\mathrm{SO}_{2}$ (after water elimination from $\mathrm{SO}_{3}{ }^{2-}$ ) to the open co-ordination site of siroheme is followed by its $2 \mathrm{e}^{-}$reduction and water elimination to result in a bound $\left[\mathrm{Fe}^{-\mathrm{III}}-\mathrm{SO}\right]^{+}$species (SO implies sulfur monoxide) where the formal oxidation state of the central sulfur is +2 i.e. $2 \mathrm{e}$ reduced relative to +4 in $\mathrm{SO}_{2}$. Two subsequent $2 \mathrm{e}^{-}$ $/ 2 \mathrm{H}^{+}$reduction and water eliminations yield the final $\mathrm{H}_{2} \mathrm{~S}$ product of this $6 \mathrm{e}^{-} / 6 \mathrm{H}^{+}$reduction of $\mathrm{SO}_{2}$. Alternatively, Stroupe and co-workers used site directed mutants of the distal Arg and Lys residues to argue for six sequential $1 \mathrm{H}^{+} / 1 \mathrm{e}^{-}$steps instead. ${ }^{25}$ Nonetheless, both mechanisms indicated the formation of unusual siroheme bound $\mathrm{SO}_{\mathrm{x}}$ species which have not been observed outside the protein matrix in heme systems. Oxidation of the sulfide bound crystals provided crystallographic evidence for the formation of the $\left[\mathrm{Fe}^{\mathrm{III}}-\mathrm{SO}\right]^{+}$species as well. The nature of these $\mathrm{Fe}-\mathrm{SO}_{\mathrm{x}}$ species has not yet been understood and this reactivity is yet to be established in synthetic systems and needs exploration.
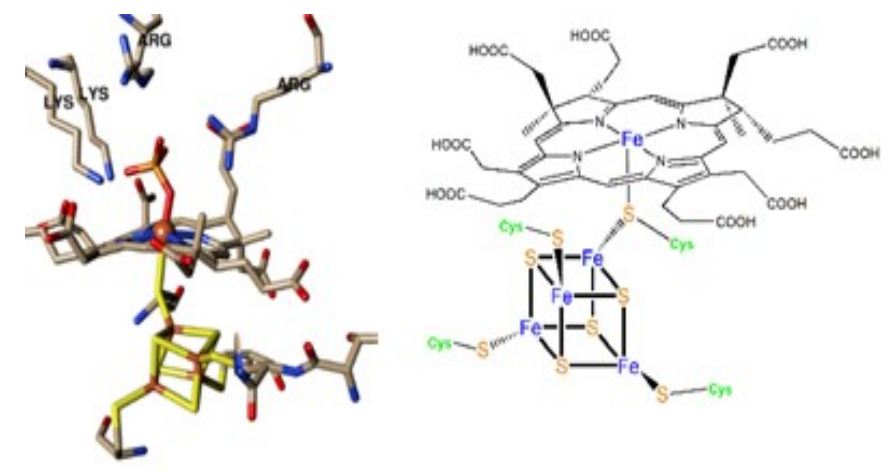

Figure 1. (left) Active site of sulfite reductase (pdb id: 1AOP). The siroheme cofactor is bound to a phosphate ion. Color code: $\mathrm{Fe} \rightarrow$ orange, $\mathrm{S} \rightarrow$ yellow, $\mathrm{P} \rightarrow$ light orange, $\mathrm{O} \rightarrow$ red, $\mathrm{N} \rightarrow$ blue and $\mathrm{C} \rightarrow$ grey. The distal pendant residues are labelled. (right) chem draw representation of the active site.

The active sites of SiR are closely related to the active site of nitrite reductases (NiR) which reduce $\mathrm{NO}_{2}{ }^{-}$to $\mathrm{NH}_{4}{ }^{+} .{ }^{26}$ Since ferrous tetraphenylporphyrin (FeTPP) can reduce $\mathrm{NO}_{2}-$ like siroheme based NiR which, in turn, can also reduce sulfite, it is possible that FeTPP may reduce $\mathrm{SO}_{2}$ like the siroheme 
based SiR. ${ }^{27}$ However, this has been difficult to achieve. While initial vibrational data indicated formation of $\mathrm{SO}_{2}$ adduct of FeTPP at $20 \mathrm{~K},{ }^{28}$ efforts to isolate the adduct or isolate reduced sulfur products failed despite several attempts to do so ${ }^{29-31}$ and sulfate/sulfite bound ferric porphyrins were isolated instead in non-protic organic solvents. Thus, even though a heme cofactor reduces $\mathrm{SO}_{2}$ in nature, reduction of $\mathrm{SO}_{2}$ by iron porphyrins has not been achieved outside of the protein matrix. In this manuscript, the reaction of iron(II) tetraphenylporphyrin (Fe ${ }^{\mathrm{II}} \mathrm{TPP}$ ) with $\mathrm{SO}_{2}$ is investigated. Crystallographic and spectroscopic characterization of the products indicate that $\mathrm{SO}_{2}$ is reduced to sulfur monoxide (SO) via a [ $\left.\mathrm{Fe}^{\mathrm{III}}-\mathrm{SO}\right]^{+}$intermediate species mimicking the first step in the catalytic cycle of SiR.

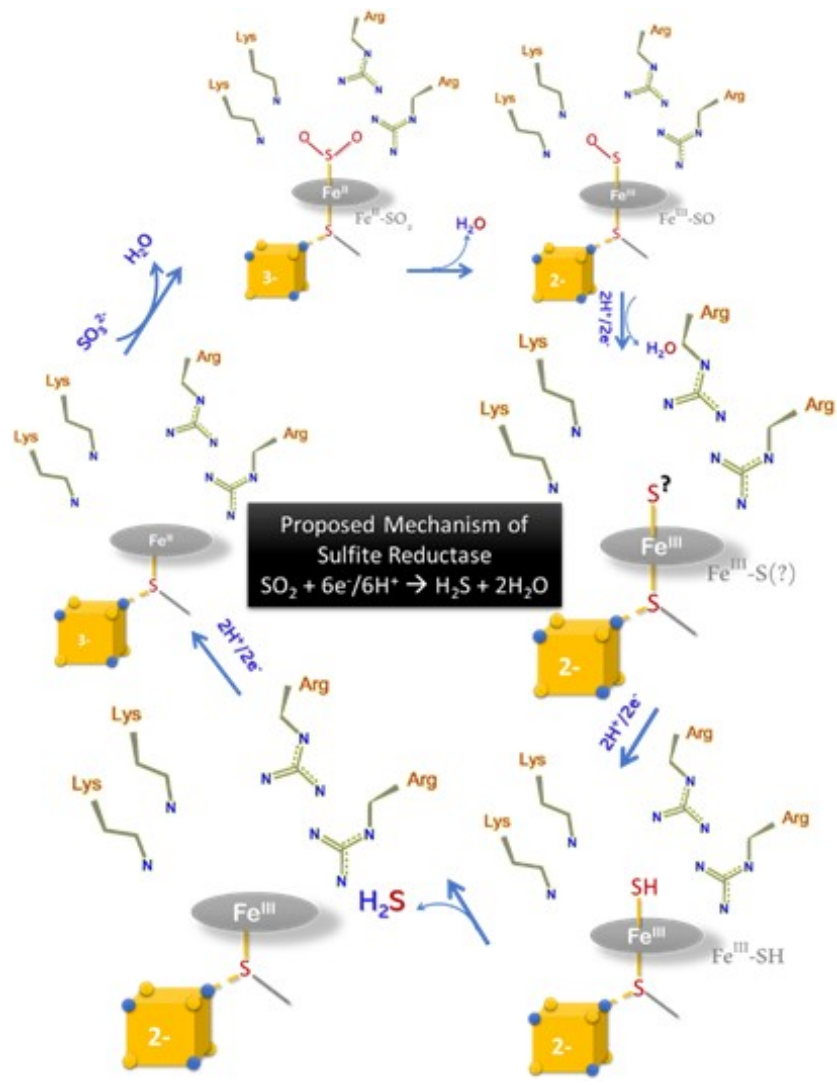

Figure 2. Proposed mechanism of $\mathrm{SO}_{2}$ reduction by the sulfite reductase. The grey ring represents the heme and the yellow cube represents the $\mathrm{Fe}_{4} \mathrm{~S}_{4}$ cluster - blue and yellow spheres represent iron and sulfide centers, respectively. The pendant lysine and arginine are indicated. In this proposed mechanism, the reaction proceeds via three $2 \mathrm{e}^{-} / 2 \mathrm{H}^{+}$steps

The reaction of ferrous tertraphenylporphyrin (Fe ${ }^{\text {IITPP, }} 10$ $\mu \mathrm{M}$ solution) with excess $\mathrm{SO}_{2}\left(\mathrm{SO}_{2}\right.$ saturated $\left.\mathrm{THF}, 0.3-0.5 \mathrm{M}\right)$ in THF solvent at room temperature (RT) leads to shift of the Soret and Q-band, characteristic of Fe IITPP, from $426 \mathrm{~nm}$ and $540 \mathrm{~nm}$ (Figure 3A, blue), respectively, to $417 \mathrm{~nm}$ and $510 \mathrm{~nm}$ (Figure 3A red), respectively, indicating the oxidation of the ferrous porphyrin to ferric porphyrin by $\mathrm{SO}_{2}$. The final spectra resemble that of a ferric porphyrin like Fe IIITPP-Cl (Fig. 3A, green). The resonance Raman data of the starting Fe IITPP exhibit a $v_{2}$ vibration at $1540 \mathrm{~cm}^{-1}$
(Figure 3B, blue) characteristic of high spin ferrous porphyrin. ${ }^{32}$ Upon the addition of $\mathrm{SO}_{2}$ the $v_{2}$ shifts to $1555 \mathrm{~cm}^{-1}$ (Figure 3B, red) which is characteristic of high spin Fe $\mathrm{Fe}^{\mathrm{III}}$ porphyrin suggesting that the $\mathrm{SO}_{2}$ oxidizes the ferrous porphyrin to its ferric state consistent with the Uv-Vis data. Letting the reaction mixture stand at RT for a day results in crystallization of a product species. The isolated purple crystals suggest the formation of a five-coordinate ferric tetraphenylporphyrin chloride species (Figure S2 left, Fe ${ }^{\text {IIITPP- }}$ Cl) with a Fe-Cl distance of $2.198 \AA$. Erstwhile efforts of investigating the reaction of $\mathrm{SO}_{2}$ with FeTPP by Holm and Scheidt resulted in the oxidation of both FeTPP and $\mathrm{SO}_{2}$ to

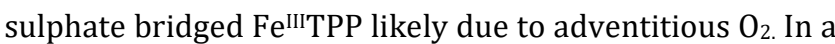
control experiment, the Fe ${ }^{I I T P P}$ is intentionally exposed to $\mathrm{O}_{2}$, a $\mu$-oxo dimer species is formed (Figure S2, right) instead of Fe ${ }^{I I I T P P}-\mathrm{Cl}$. Thus, any possible interference from accidental $\mathrm{O}_{2}$ leak in the reaction as well as interference from the reductant used can be eliminated.
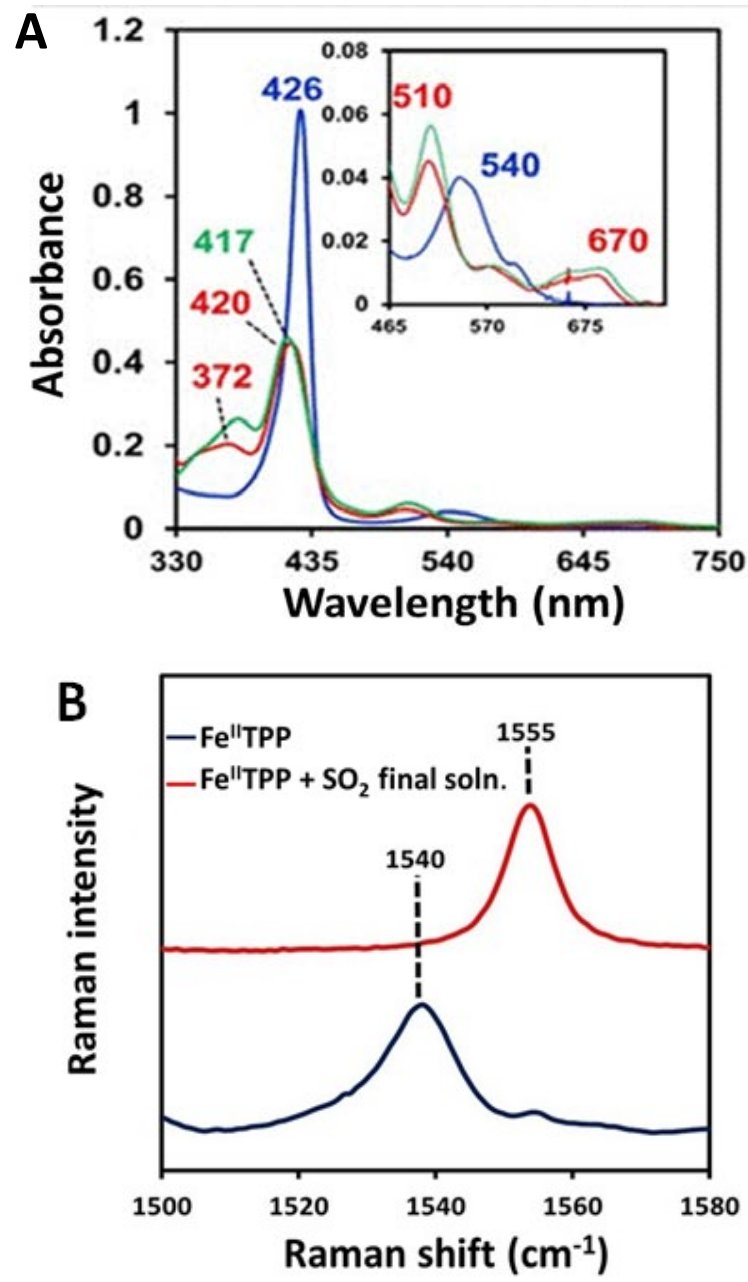

Figure 3. (A) Absorption data of the reduced FeIITPP (blue) and the resulting species (red) after $\mathrm{SO}_{2}$ addition and $\mathrm{Fe}^{\text {IIITPP-Cl }}$ (green) (B) The resonance Raman data of the reacting Fe ${ }^{I I T P P}$ (blue), the product after $\mathrm{SO}_{2}$ addition (red).

The reaction of Fe ${ }^{\text {IITPP }}$ with $\mathrm{SO}_{2}$ at $\mathrm{RT}$ did not reveal any intermediates that may be involved. The EPR spectra of the reaction mixture at $-40^{\circ} \mathrm{C}$ shows two new species when $\mathrm{SO}_{2}$ 
is added to the EPR silent Fe ${ }^{\mathrm{IITPP}}$ (Figure 4, blue) reactant. First, a signal at $\mathrm{g}=5.96$ which is characteristic of a high spin $\mathrm{Fe}^{\mathrm{III}}$ species and second, another signal having $\mathrm{g}_{1}$ and $\mathrm{g}_{2}$ values of 2.06 and 1.98 which indicates the formation of a lowspin $\mathrm{S}=1 / 2 \mathrm{Fe}^{\mathrm{III}}$ species (Figure 4 , red) as well. The signal at 5.96 is typical of a high spin ferric porphyrin (Figure 4, green, Fe ${ }^{\text {IIITPP-Cl}}$. The nature of the $\mathrm{S}=1 / 2$ product EPR is quite different from those commonly observed in low spin ferric species (very narrow g-values) instead it is very similar to the EPR signal of exchange-coupled $S=1 / 2$ ferrous nitrosyl adducts of heme and non-heme [FeNO] ${ }^{7}$ (EnemarkFeltham notation $)^{33}$ species. ${ }^{34-37}$ Analogously, this signal can originate from a $\left[\mathrm{Fe}^{\mathrm{III}}-\mathrm{SO}\right]^{+}$or $[\mathrm{FeSO}]^{8}$ species produced from a $2 \mathrm{e}^{-}$reduction of $\mathrm{SO}_{2}$ akin to the first reduction step in $\mathrm{SiR}$ (scheme 1). Although there are no precedence of EPR of metal bound SO complexes, SO has a triplet ground state like $\mathrm{O}_{2}{ }^{38}$ and an anti-ferromagnetic coupling of a $\mathrm{S}=1 / 2 \mathrm{Fe}^{\mathrm{III}}$ with an $S=1$ SO is expected to result in a $S=1 / 2$ ground state with an EPR signal like those reported for $[\mathrm{FeNO}]^{7}$ species, which are described as $\mathrm{S}=1 / 2 \mathrm{Fe}^{\mathrm{III}}$ center anti-ferromagnetically coupled to a $S=1$ NO. ${ }^{36,39-40}$ Note that these signals are very different from $\mathrm{SO}_{2}^{-}$radical has a typical sharp signal with $\mathrm{g}$ values on 2.008-2.005.41-42

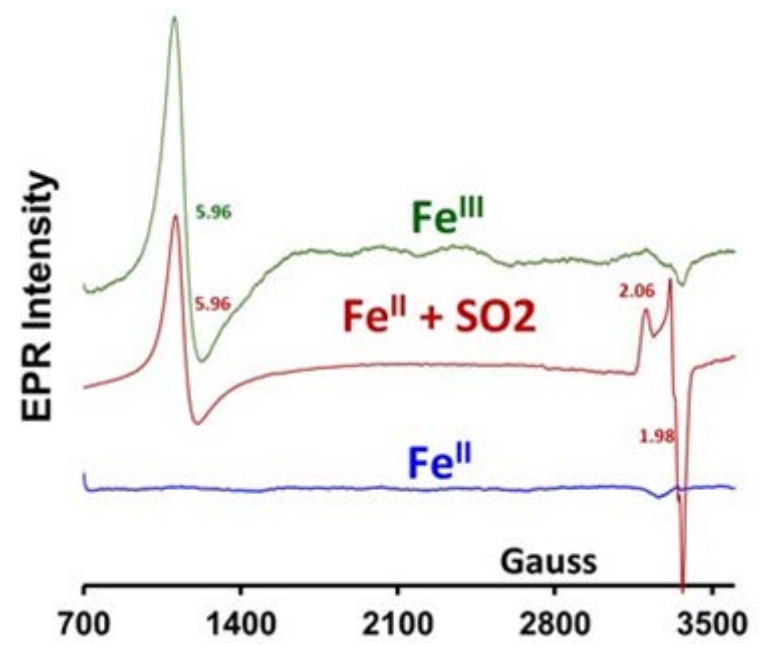

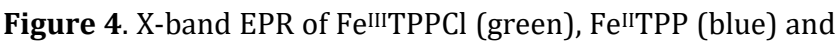
the product of FelITPP reaction with $\mathrm{SO}_{2}$ (green) collected at $77 \mathrm{~K}$.

The species with a low spin Fe ${ }^{\text {III }}$ EPR signal, likely to be $\left[\mathrm{Fe}^{\mathrm{III}}-\mathrm{SO}\right]^{+}$, is further investigated using Mossbauer and resonance Raman spectroscopy. The Mossbauer spectra of the reaction mixture show three components. A species (52\%) having $\delta_{\text {iso }}=0.22 \mathrm{~mm} / \mathrm{s}$ and $\Delta \mathrm{Eq}=0.60 \mathrm{~mm} / \mathrm{s}$, a species (46\%) having $\delta_{\text {iso }}=0.20 \mathrm{~mm} / \mathrm{s}$ and $\Delta \mathrm{Eq}=2.35 \mathrm{~mm} / \mathrm{s}$ (Figure 5 . blue line) and a minor ( $\sim 2 \%)$ species having $\delta_{\text {iso }}=0.55$ $\mathrm{mm} / \mathrm{s}$ and $\Delta \mathrm{Eq}=1.90 \mathrm{~mm} / \mathrm{s}$ is observed. Based on the observed $\delta_{\text {iso }}$ and $\Delta \mathrm{E}_{\mathrm{q}}$ values, these species corresponds to a high spin Fe ${ }^{\mathrm{III}} \mathrm{TPP}$ species (EPR g=5.96), a [Fe ${ }^{\mathrm{III}}$-SO $]^{+}$species (g values 2.06, 1.98) which has a low spin Fe $\mathrm{Fe}^{\mathrm{III}}$ center and

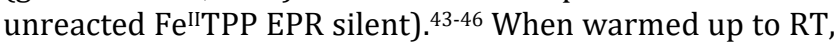
the spectra show (Figure 5. yellow line) that the population of the low spin $\mathrm{Fe}^{\mathrm{III}}$ species is reduced relative to the data obtained for the reaction mixture at $-40^{\circ} \mathrm{C}$ consistent with the decay of a low $\mathrm{S}=1 / 2$ [ $\left.\mathrm{Fe}^{\mathrm{III}}-\mathrm{SO}\right]^{+}$intermediate to a high spin ferric porphyrin species. The resonance Raman and Uv-Vis data of the product obtained at RT show only a high spin ferric porphyrin species as the product which is consistent with the observed decay of the $S=1 / 2$ [Fe III-SO] $^{+}$intermediate species to the high spin ferric porphyrin product.

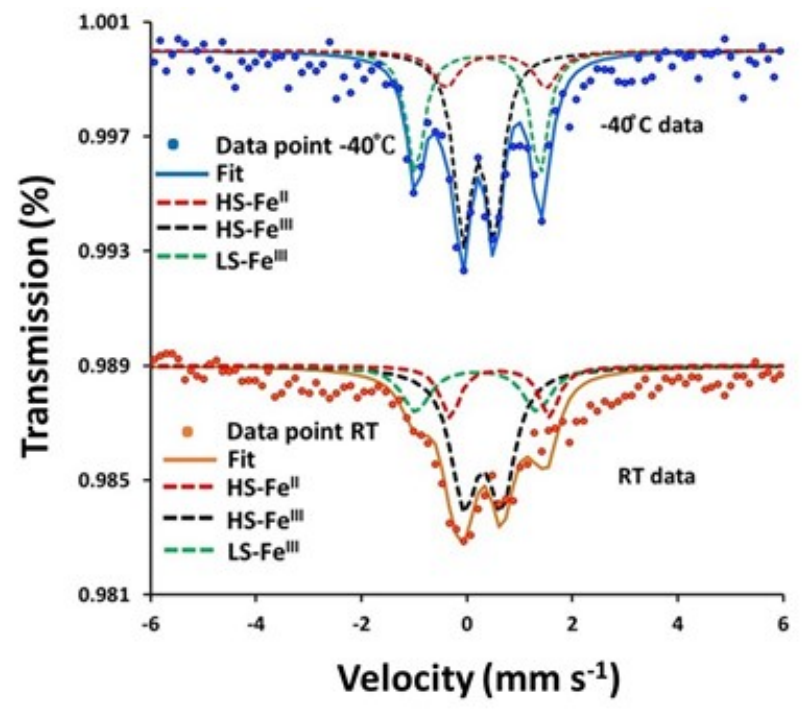

Figure 5. ${ }^{57} \mathrm{Fe}$ Mossbauer spectra (95K, zero field) of $\mathrm{Fe}{ }^{\mathrm{IITPP}}+\mathrm{SO}_{2}(\mathrm{~g})$ mixture prepared at $-40^{\circ} \mathrm{C}$ (blue trace) and at RT (yellow trace), respectively, along with the fits. The relative population of high spin Fe ${ }^{\mathrm{III}}$, low spin $\mathrm{Fe}^{\mathrm{III}}$ and high spin $\mathrm{Fe}^{\mathrm{II}}$ species in the sample prepared at $-40^{\circ} \mathrm{C}$ are $46 \%, 52 \%$ and $2 \%$, respectively.
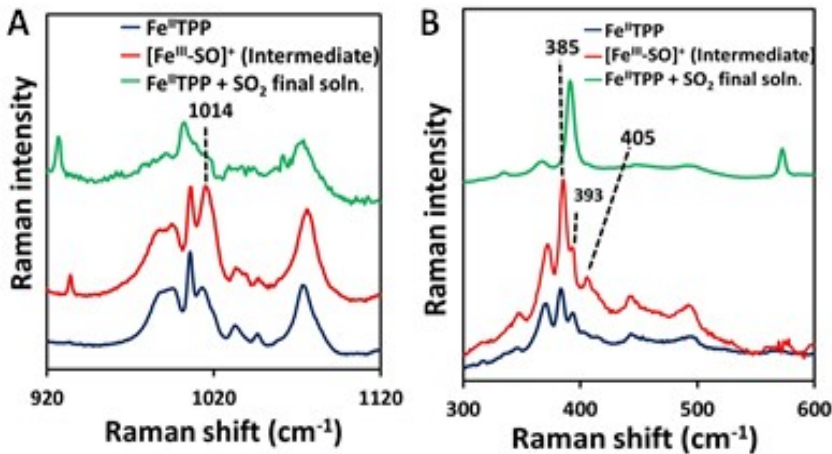

Figure 6. resonance Raman spectra of Fe ${ }^{I I T P P}$,(blue line) reaction mixture of $\mathrm{Fe} \mathrm{IITP}^{\mathrm{II}}+\mathrm{SO}_{2}$ at $-40^{\circ} \mathrm{C}$ containing intermediate $\left[\mathrm{Fe}^{\mathrm{III}}-\mathrm{SO}\right]^{+}$(red line) and final solution product of $\mathrm{Fe}$ IITPP $+\mathrm{SO}_{2}$ at RT (green line).

The resonance Raman spectra of the same reaction mixture (prepared at $-40^{\circ} \mathrm{C}$ ) exhibit $\mathrm{v}_{2}$ marker band (Fe- $\mathrm{N}_{\text {pyrrole }}$ symmetric stretching) at $385 \mathrm{~cm}^{-1}$ with a shoulder at $393 \mathrm{~cm}^{-1}$ as may be expected due to the presence of both high spin $\left[\mathrm{Fe}^{\mathrm{IIITPP}}\right]^{+}$species and low spin [Fe $\left.\mathrm{Fe}_{-}^{\mathrm{III}}-\mathrm{SO}\right]^{+}$species in the solution. ${ }^{47-48} \mathrm{New}$ vibrations are observed at $1014 \mathrm{~cm}^{-1}$ and $405 \mathrm{~cm}^{-1}$ (Figure 6A and 6B red line) which are absent in the reactant Fe ${ }^{\mathrm{IIT}}$ TPP species (Figure $6 \mathrm{~A}$ and $6 \mathrm{~B}$ blue line) as well as in the final product (at RT) of the reaction (Figure $6 \mathrm{~A}$ and $6 \mathrm{~B}$ green line), respectively. The $1014 \mathrm{~cm}^{-1}$ peak is con-

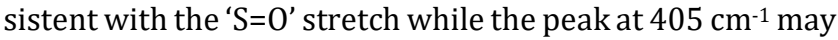
represent the $\mathrm{Fe}-\mathrm{S}$ stretch of the $\left[\mathrm{Fe}^{\mathrm{III}}-\mathrm{SO}\right]^{+}$intermediate species. Note that these assignments need isotopically labelled $\mathrm{SO}_{2}$ to be confirmed which is expensive and beyond the scope of this study. 
The EPR, Mossbauer and resonance Raman data all indicate that a mixture of high spin [FeIIIPP $]^{+}$and low spin [Fe $\left.{ }^{\mathrm{III}}-\mathrm{SO}\right]^{+}$ intermediate species are initially produced when $\mathrm{SO}_{2}$ reacts with FeIITPP. Furthermore, the Mossbauer data indicate that the population of the high spin [Fe $\left.{ }^{\mathrm{III}} \mathrm{TPP}\right]^{+}$and low spin [ $\mathrm{Fe}^{\mathrm{III}}$ $\mathrm{SO}^{+}$species is $\sim 0.9: 1$ suggesting that these two ferric species are produced simultaneously as suggested by the EPR data obtained under the same conditions. These experimental data are suggestive of a $2 \mathrm{e}^{-}$reduction of $\mathrm{SO}_{2}$ where one electron is derived from a free Fe ${ }^{\mathrm{II}} \mathrm{TPP}$ in solution and the other is obtained from the ferrous porphyrin that binds the $\mathrm{SO}_{2}$ and results in the low-spin [ $\left.\mathrm{Fe}^{\mathrm{III}}-\mathrm{SO}\right]^{+}$intermediate (Scheme 1). The protons required for the water elimination can be obtained from $\mathrm{MeOH}$ used in the reaction mixture or any residual water in the solvent used. Note that EP, Mossbauer as well as resonance Raman data indicate that this $\mathrm{S}=1 / 2$ [Fe $\mathrm{Fe}^{\mathrm{II}}$ $\mathrm{SO}^{+}$species is an intermediate of the reaction and its solvolysis results in the formation of high spin ferric porphyrin which automatically entails the release of SO.

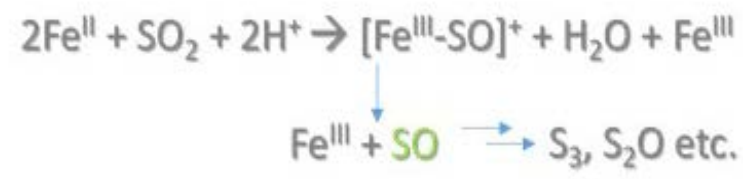

Scheme 1: Possible products resulting from $2 \mathrm{e}^{-} \mathrm{SO}_{2}$ reduction.

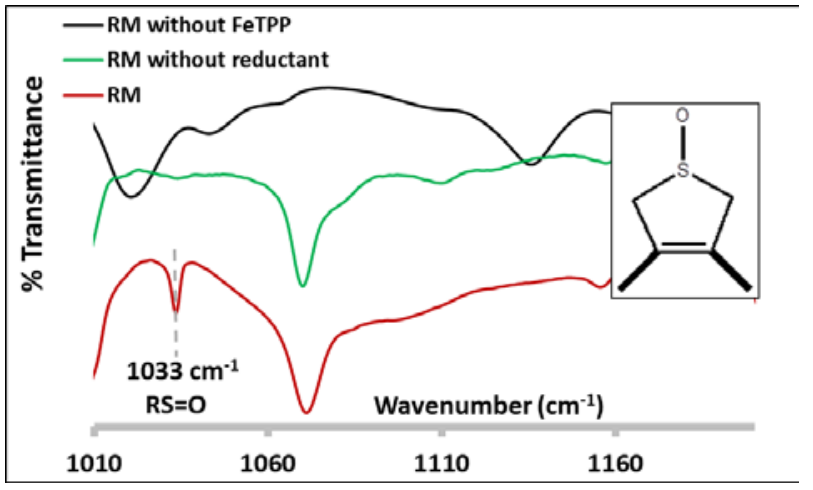

Figure 7. FTIR data of the reaction mixture (RM) in red, RM without reductant in green and RM without FeTPP in black. Inset-Mass spectra of DMB-SO done in GCMS.

SO is an exotic unstable molecule and has a lifetime of $<1$ s at RT. ${ }^{49}$ However, its formation may be evidenced using Diels-Alder (DA) reaction with dienes as has been established for organic SO donors. ${ }^{50}$ The reaction of Fe ${ }^{\text {IITPP }}$ with $\mathrm{SO}_{2}$ when incubated with 2,3-dimethylbutadiene (DMB) exhibit a new vibration in the FTIR spectra at $1033 \mathrm{~cm}^{-1}$ (Figure 7. red) which is identical to that of an independently synthesized sulfoxide adduct of DMB. The SO transfer to DMB is further confirmed by GCMS data of the reaction mixture, which shows a peak with a mass of 130 a.u. consistent with the formation of the DA adduct (Figure 7. inset). The control samples which lack the reductant or Fe ${ }^{\mathrm{II}} \mathrm{TPP}$ only results in the expected DA adduct of $\mathrm{SO}_{2}$ and no sulfoxide is observed either in the FTIR or in GCMS (Figure S3 and Figure S4). ${ }^{30-31}$ The GC yield of the DA adduct of DMB + SO
(DMB-SO, Fig. 7, inset)) is $32-48 \%$ between different runs with respect to FeIITPP used (expected yield $50 \%$ as one DMB-SO is produced per two equivalent of Fe ${ }^{\text {IITPP). SO }}$ transfer from organic SO donors have yield ranging between $10-20 \% .^{51}$

In summary, the data show that ferrous porphyrin can reduce $\mathrm{SO}_{2}$ mimicking the function of siroheme based sulfite reductase. The reaction follows a $2 \mathrm{e}^{-} / 2 \mathrm{H}^{+}$pathway to generate a $\mathrm{S}=1 / 2$ [Fe III-SO] $^{+}$species which releases SO. The resultant SO species was evidenced by trapping its DA adduct with DMB. This is the first report of chemical reduction of $\mathrm{SO}_{2}$ by synthetic ferrous porphyrins mimicking the reaction of sulfite reductase outside the protein matrix. The observation of a $\left[\mathrm{Fe}^{\mathrm{III}}-\mathrm{SO}\right]^{+}$species outside the protein matrix heralds the possibility of accessing several other unusual intermediates proposed to be involved in this $6 \mathrm{e}^{-} / 6 \mathrm{H}^{+}$process in this enzyme. These results will enable a deeper understanding of the mechanism of SiR's and aid mimicking its function in artificial systems.

\section{ASSOCIATED CONTENT}

Experimental details and methods used are available online at https://pubs.acs.org.

\section{AUTHOR INFORMATION}

\section{Corresponding Author}

* Abhishek Dey

\section{Author Contributions}

${ }^{\ddagger}$ A.B., A.K.N., and A.G. contributed equally.

\section{Funding Sources}

This research is sponsored by Department of Science and Technology, India grant EMR-008063 and CRG/2020/000561

\section{ACKNOWLEDGMENT}

A.B., A.K.N. and A.G. acknowledge University Grants Commission Fellowship and A.N. acknowledge DST Inspire Fellowship program. Ms. Manjistha Mukherjee is acknowledged for her help with GCMS.

\section{REFERENCES}

1. Zhong, Q.; Shen, H.; Yun, X.; Chen, Y.; Ren, Y. a.; Xu, H.; Shen, G.; Du, W.; Meng, J.; Li, W.; Ma, J.; Tao, S., Global Sulfur Dioxide Emissions and the Driving Forces. Environmental Science \& Technology 2020, 54 (11), 6508-6517.

2. Qu, Z.; Henze, D. K.; Li, C.; Theys, N.; Wang, Y.; Wang, J.; Wang, W.; Han, J.; Shim, C.; Dickerson, R. R.; Ren, X., SO2 Emission Estimates Using OMI SO2 Retrievals for 2005-2017. Journal of Geophysical Research: Atmospheres 2019, 124 (14), 8336-8359.

3. Kato, N.; Akimoto, H., Anthropogenic emissions of SO2 and NOx in Asia: emission inventories. Atmospheric Environment. Part A. General Topics 1992, 26 (16), 2997-3017. 
4. Arndt, R. L.; Carmichael, G. R.; Streets, D. G.; Bhatti, N., Sulfur dioxide emissions and sectorial contributions to sulfur deposition in Asia. Atmospheric Environment 1997, 31 (10), 1553-1572.

5. Clark, N. A.; Demers, P. A.; Karr, C. J.; Koehoorn, M.; Lencar, C.; Tamburic, L.; Brauer, M., Effect of early life exposure to air pollution on development of childhood asthma. Environ Health Perspect 2010, 118 (2), 284-290. 6. Huang, Y.; Shen, H.; Chen, H.; Wang, R.; Zhang, Y.; Su, S.; Chen, Y.; Lin, N.; Zhuo, S.; Zhong, Q.; Wang, X.; Liu, J.; Li, B.; Liu, W.; Tao, S., Quantification of Global Primary Emissions of PM2.5, PM10, and TSP from Combustion and Industrial Process Sources. Environmental Science \& Technology 2014, 48 (23), 13834-13843.

7. McNeill, V. F., Addressing the Global Air Pollution Crisis: Chemistry's Role. Trends in Chemistry 2019, 1 (1), 5-8.

8. $\quad$ Feng, T.; Huo, M.; Zhao, X.; Wang, T.; Xia, X.; Ma, C., Reduction of SO2 to elemental sulfur with $\mathrm{H} 2$ and mixed $\mathrm{H} 2 / \mathrm{CO}$ gas in an activated carbon bed. Chemical Engineering Research and Design 2017, 121, 191-199.

9. $\quad$ Feng, T.; Zhao, X.; Wang, T.; Xia, X.; Zhang, M.; Huan, Q.; Ma, C., Reduction of SO2 with CO to Elemental Sulfur in Activated Carbon Bed. Energy \& Fuels 2016, 30 (8), 6578-6584.

10. Han, G. B.; Park, N.-K.; Yoon, S. H.; Lee, T. J.; Han, G. Y., Direct Reduction of Sulfur Dioxide to Elemental Sulfur with Hydrogen over Sn-Zr-Based Catalysts. Industrial \& Engineering Chemistry Research 2008, 47 (14), 4658-4664.

11. AlQahtani, M. S.; Knecht, S. D.; Wang, X.; Bilén, S. G.; Song, C., One-Step Low-Temperature Reduction of Sulfur Dioxide to Elemental Sulfur by Plasma-Enhanced Catalysis. ACS Catalysis 2020, 10 (9), 5272-5277.

12. Wei, R.; Chen, X.; Gong, Y., Side-On Sulfur Monoxide Complexes of Tantalum, Niobium, and Vanadium Oxyfluorides. Inorganic Chemistry 2019, 58 (6), 3807-3814.

13. Kline, M. A.; Barley, M. H.; Meyer, T. J., Electrocatalytic reduction of bisulfite to hydrogen sulfide based on a water-soluble iron porphyrin. Inorganic Chemistry 1987, 26 (14), 2196-2197.

14. Wayland, B. B.; Mohajer, D., An electron spin resonance study of the interaction of sulphur dioxide with tetraphenylporphyrincobalt(II). Journal of the Chemical Society, Chemical Communications 1972, (13), 776-777.

15. Pandey, K. K.

16. Schenk, W. A., Sulfur Oxides as Ligands in Coordination Compounds. Angewandte Chemie International Edition in English 1987, 26 (2), 98-109.

17. Gong, J. K.; Fanwick, P. E.; Kubiak, C. P., A sulphur monoxide-bridged dinickel a-frame complex: $[\mathrm{Ni} 2(\mu-$ SO)(PPh2CH2PPh2)2Cl2]. Journal of the Chemical Society, Chemical Communications 1990, (17), 11901191.

18. Chahal, M.; Raje, S.; Kotana, G.; Angamuthu, R., Binding enabled catalytic activation of SO2 by copper koneramine complexes under ambient conditions. Green Chemistry 2019, 21 (23), 6372-6380.

19. Sun, J.; Li, L.; Zhou, G.; Wang, X.; Zhang, L.; Liu, Y.; Yang, J.; Lü, X.; Jiang, F., Biological Sulfur Reduction To Generate H2S As a Reducing Agent To Achieve Simultaneous Catalytic Removal of SO2 and NO and Sulfur Recovery from Flue Gas. Environmental Science \& Technology 2018, 52 (8), 4754-4762.

20. Murphy, M. J.; Siegel, L. M.; Tove, S. R.; Kamin, H., Siroheme: a new prosthetic group participating in sixelectron reduction reactions catalyzed by both sulfite and nitrite reductases. Proc Natl Acad Sci U S A 1974, 71 (3), 612-616.

21. Crane, B. R.; Siegel, L. M.; Getzoff, E. D., Sulfite Reductase Structure at 1.6 ̊̊: Evolution and Catalysis for Reduction of Inorganic Anions. Science 1995, 270 (5233), 59.

22. Brânzanic, A. M. V.; Ryde, U.; Silaghi-Dumitrescu, R., Why does sulfite reductase employ siroheme? Chemical Communications 2019, 55 (93), 14047-14049. 23. Lui, S. M.; Cowan, J. A., Direct Reversible Protein Electrochemistry at a Pyrolytic Graphite Electrode. Characterization of the Redox Thermodynamics of the Fe4S4-Siroheme Prosthetic Center in the Hexameric Dissimilatory Sulfite Reductase and the Monomeric Assimilatory Sulfite Reductase from Desulfovibrio vulgaris (Hildenborough). Systematic pH Titration Experiments and Implications for Active Site Chemistry. Journal of the American Chemical Society 1994, 116 (25), 11538-11549.

24. Crane, B. R.; Siegel, L. M.; Getzoff, E. D., Probing the Catalytic Mechanism of Sulfite Reductase by X-ray Crystallography: Structures of the Escherichia coli Hemoprotein in Complex with Substrates, Inhibitors, Intermediates, and Products. Biochemistry 1997, 36 (40), 12120-12137.

25. Smith, K. W.; Stroupe, M. E., Mutational Analysis of Sulfite Reductase Hemoprotein Reveals the Mechanism for Coordinated Electron and Proton Transfer. Biochemistry 2012, 51 (49), 9857-9868.

26. Maia, L. B.; Moura, J. J. G., How Biology Handles Nitrite. Chemical Reviews 2014, 114 (10), 5273-5357.

27. Lukat, P.; Rudolf, M.; Stach, P.; Messerschmidt, A.; Kroneck, P. M. H.; Simon, J.; Einsle, O., Binding and Reduction of Sulfite by Cytochrome c Nitrite Reductase. Biochemistry 2008, 47 (7), 2080-2086.

28. Kuroi, T.; Nakamoto, K., Matrix-isolation infrared spectra of oxy(tetraphenylporphyrinato)iron(II) containing CS2 and SO2 as axial ligands. Journal of Molecular Structure 1986, 146, 111-121.

29. Reynolds, M. S.; Holm, R. H., Binding of oxysulfur anions to macrocyclic iron(II,III): [(Fe(TPP))2SO4] and Fe(Me6[14]-4,11-dieneN4)(S205)]. Inorganica Chimica Acta 1989, 155 (1), 113-123.

30. Cocolios, P.; Lagrange, G.; Guilard, R.; Oumous, H.; Lecomte, C., Alkane (or arene)-sulphinato and sulphonato-iron(III) porphyrins: synthesis and physicochemical properties; crystal structure of 
benzenesulphinato $(5,10,15,20$ -

tetraphenylporphyrinato)iron(III). Journal of the Chemical Society, Dalton Transactions 1984, (4), 567574.

31. Scheidt, W. R.; Lee, Y. J.; Finnegan, M. G., Reactions of sulfur dioxide with iron porphyrinates and the crystal structure of (hydrogen sulfato)(tetraphenylporphinato)iron(III) hemibenzene solvate. Inorganic Chemistry 1988, 27 (26), 4725-4730.

32. Burke, J. M.; Kincaid, J. R.; Peters, S.; Gagne, R. R.; Collman, J. P.; Spiro, T. G., Structure-sensitive resonance Raman bands of tetraphenyl and "picket fence" porphyrin-iron complexes, including an oxyhemoglobin analog. Journal of the American Chemical Society 1978, 100 (19), 6083-6088.

33. Enemark, J. H.; Feltham, R. D., Principles of structure, bonding, and reactivity for metal nitrosyl complexes. Coordination Chemistry Reviews 1974, 13 (4), 339-406.

34. Praneeth, V. K. K.; Näther, C.; Peters, G.; Lehnert, N., Spectroscopic Properties and Electronic Structure of Five- and Six-Coordinate Iron(II) Porphyrin NO Complexes: Effect of the Axial N-Donor Ligand. Inorganic Chemistry 2006, 45 (7), 2795-2811.

35. Walker, F. A., Models of the Bis-HistidineLigated Electron-Transferring Cytochromes. Comparative Geometric and Electronic Structure of LowSpin Ferro- and Ferrihemes. Chemical Reviews 2004, 104 (2), 589-616.

36. Tangen, E.; Conradie, J.; Ghosh, A., The Challenge of Being Straight: Explaining the Linearity of a Low-Spin \{FeNO\}7 Unit in a Tropocoronand Complex. Inorganic Chemistry 2005, 44 (24), 8699-8706.

37. Raynor, J. B., Electron Spin Resonance Spectrum of the Pentacyanonitrosylferrate (I) Anion. Nature 1964, 201 (4925), 1216-1217.

38. Ishikawa, Y.; Gong, Y.; Weiner, B. R., Gaussian-2 theoretical and direct ab initio molecular dynamics study of the reaction of $\mathrm{O}(3 \mathrm{P})$ with thiirane, $\mathrm{O}(3 \mathrm{P})+$ $\mathrm{C} 2 \mathrm{H} 4 \mathrm{~S}(1 \mathrm{~A} 1) \rightarrow \mathrm{SO}\left(3 \Sigma_{-}\right)+\mathrm{C} 2 \mathrm{H} 4(1 \mathrm{Ag})$. Physical Chemistry Chemical Physics 2000, 2 (4), 869-876.

39. Goussias, C.; Deligiannakis, Y.; Sanakis, Y.; Ioannidis, N.; Petrouleas, V., Probing Subtle Coordination Changes in the Iron-Quinone Complex of Photosystem II during Charge Separation, by the Use of NO. Biochemistry 2002, 41 (51), 15212-15223.

40. Franz, K. J.; Lippard, S. J., NO Disproportionation Reactivity of $\mathrm{Fe}$ Tropocoronand Complexes. Journal of the American Chemical Society 1999, 121 (45), 1050410512.

41. Rinker, R. G.; Gordon, T. P.; Mason, D. M.; Corcoran, W. H., The Presence of the SO2 Radical Ion in Aqueous Solutions of Sodium Dithionite. The Journal of Physical Chemistry 1959, 63 (2), 302-302.

42. Livraghi, S.; Paganini, M. C.; Giamello, E., SO2 reactivity on the $\mathrm{MgO}$ and $\mathrm{CaO}$ surfaces: $\mathrm{ACW}$-EPR study of oxo-sulphur radical anions. Journal of Molecular Catalysis A: Chemical 2010, 322 (1), 39-44.
43. Ellison, M. K.; Schulz, C. E.; Scheidt, W. R., Structural and Electronic Characterization of Nitrosyl(Octaethylporphinato)iron(III) Perchlorate Derivatives. Inorganic Chemistry 2000, 39 (22), 51025110.

44. Marchant, L.; Sharrock, M.; Hoffman, B. M.; Münck, E., Study of an oxygenated heme complex in frozen solution by Mössbauer emission spectroscopy. Proc Natl Acad Sci U S A 1972, 69 (9), 2396-2399.

45. Iijima, S.; Mizutani, F.; Niwa, O.; Matsumoto, N.; Sunatsuki, Y.; Kojima, M., Mössbauer studies of mixedvalence spin-crossover iron complexes with a hexadentate tripod ligand. Hyperfine Interactions 2005, 166 (1), 397-402.

46. Wyllie, G. R. A.; Schulz, C. E.; Scheidt, W. R., Fiveto Six-Coordination in (Nitrosyl)iron(II) Porphyrinates: Effects of Binding the Sixth Ligand. Inorganic Chemistry 2003, 42 (18), 5722-5734.

47. Cheam, T. C.; Krimm, S., Vibrational analysis of crystalline diketopiperazine-I. Raman and i.r. spectra. Spectrochimica Acta Part A: Molecular Spectroscopy 1984, 40 (6), 481-501.

48. Burke, J. M.; Kincaid, J. R.; Spiro, T. G., Resonance Raman spectra and vibrational modes of iron(III) tetraphenylporphine .mu.-oxo dimer. Evidence for phenyl interaction and lack of dimer splitting. Journal of the American Chemical Society 1978, 100 (19), 60776083.

49. Schenk, P. W.; Steudel, R., New Finding in the Chemistry of the Lower Oxides of Sulfur. Angewandte Chemie International Edition in English 1965, 4 (5), 402409.

50. Grainger, R. S.; Patel, B.; Kariuki, B. M.; Male, L.; Spencer, N., Sulfur Monoxide Transfer from periSubstituted Trisulfide-2-oxides to Dienes: Substituent Effects, Mechanistic Studies and Application in Thiophene Synthesis. J Am Chem Soc 2011, 133 (15), 5843-5852.

51. Dodson, R. M.; Sauers, R. F., Sulphur monoxide: reaction with dienes. Chemical Communications (London) 1967, (22), 1189-1190. 


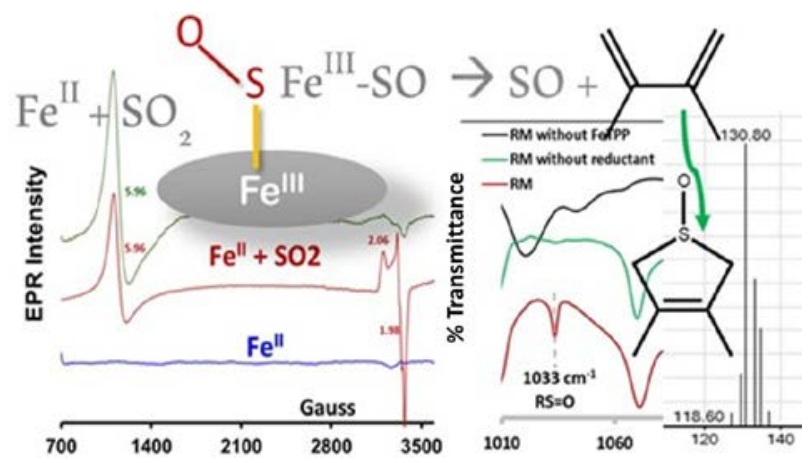




\title{
Supporting Information
}

for

\section{Reduction of Sulfur Dioxide to Sulfur Monoxide by Ferrous Porphyrin}

\author{
Aishik Bhattacharya, ${ }^{\ddagger}$ Arnab Kumar Nath, ${ }^{\ddagger}$ Arnab Ghatak, ${ }^{\ddagger}$ Abhijit Nayek, Rajat Saha, \\ Somdatta Ghosh Dey*, Abhishek Dey*
}

School of Chemical Sciences, Indian Association for the Cultivation of Science, 2A \& 2B

Raja S. C. Mullick Road, Jadavpur, Kolkata, 700032 


\section{Materials and Methods:}

\section{i) Materials:}

All the reagents used were ensured to be of best commercially available quality. $\mathrm{H}_{2} \mathrm{SO}_{4}$ (98\%, Merck), $\mathrm{Na}_{2} \mathrm{SO}_{3}$ (anhydrous, Merck), $\mathrm{HCl}$ (37\%, Merck), Silica (Merck), $\mathrm{Na}_{2} \mathrm{SO} 4$ (Merck), all were bought from respective vendors and used without further purification. Benzaldehyde (Spectrochem), Pyrrole (Spectrochem), Glacial Acetic acid (Spectrochem), $\mathrm{Na}_{2} \mathrm{~S}$ (Spectrochem) were bought from respective vendors. 2,4,6-Trimethylpyridine (Sigma-Aldrich), Ferrous Bromide (anhydrous, Sigma-Aldrich) were used for Fe ${ }^{\mathrm{III}} \mathrm{TPP}$ synthesis. Tetrahydrofuran, Methanol, Hexane were sourced from Finar Chemicals and used only after subjecting them to adequate drying and distilling procedures. Dry and pure $\mathrm{SO}_{2}$ gas was passed through a solution of conc. $\mathrm{H}_{2} \mathrm{SO}_{4}$ to remove any moisture and tested using GCMS prior to use. The solubility of $\mathrm{SO}_{2}$ in THF (after 20 mins purging) is assumed to be $0.3-0.5 \mathrm{M}$ as is the case for commercial sources of the same (https://www.sigmaaldrich.com/catalog/product/aldrich/901592). ${ }^{57} \mathrm{Fe}$ samples were synthetized by using ${ }^{57} \mathrm{FeCl}_{2}$ to metallate TPP.

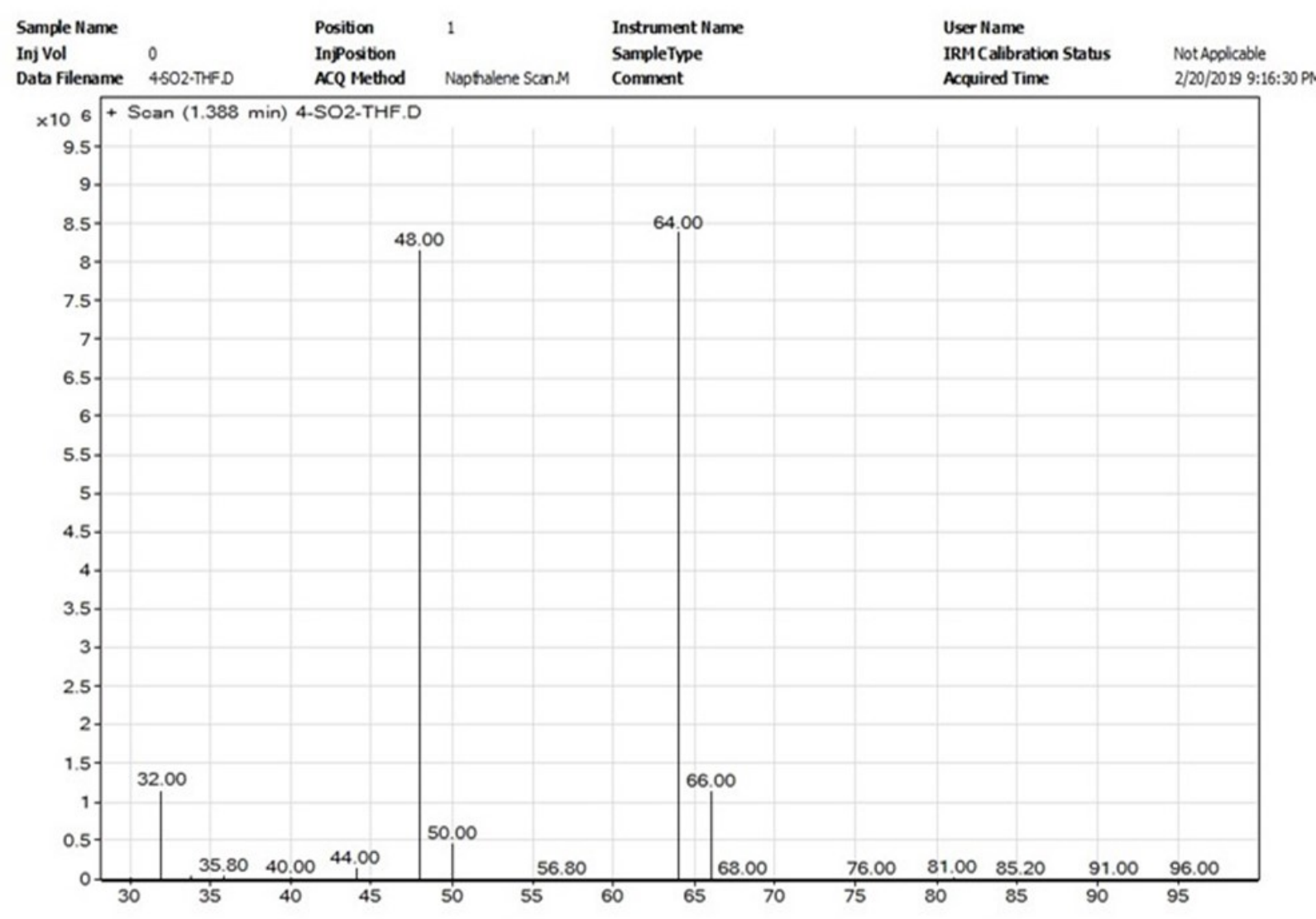

Absorption spectra were obtained by a UV-Vis diode array spectrophotometer (Agilent 8453). EPR experiments were performed at $77 \mathrm{~K}$ in a liquid nitrogen finger dewar. EPR spectra were obtained by a JEOL FA200 spectrophotometer with the following parameters- modulation width: 10 gauss; amplitude: 20; time constant: $300 \mathrm{~ms}$; power: $2 \mathrm{~mW}$; frequency: $9.25 \mathrm{GHz}$. For GCMS an Agilent 7890B GC system with a 5977A MS detector was used. Resonance Raman (rR) data were collected using $413.1 \mathrm{~nm}$ excitation from a $\mathrm{Kr}+$ ion source (Sabre Coherent Inc.) and a Trivista 555 triple spectrophotometer (gratings used in the three stages were 900, 900, and 2400 grooves $/ \mathrm{mm}$ ) fitted with 
an electronically cooled Pixis CCD camera (Princeton Instruments). The irradiation power kept at the sample is $8-10 \mathrm{~mW}$, so that photodegradation does not take place. All the data were collected at $77 \mathrm{~K}$ in a liquid $\mathrm{N}_{2}$ cooled finger Dewar after preparing the reaction mixtures at the room temperature. The FT-IR data were measured on a Perkin Elmer spectrophotometer (Frontier) instrument. Data were collected by drop casting the sample over $\mathrm{CaF}_{2}$ window and taking dry hexane/air background in LiTa mode at room temperature. Mossbauer data are obtained in a Wissenschaftliche Elektronik GmbH (WissEl) Mossbauer Spectrometer fitted with a $50 \mathrm{mC}{ }^{57} \mathrm{Co}$ source. The samples were immersed in a Janis liq. $\mathrm{N}_{2}$ cryostat with a sample holder for home-built nylon sample cell. The doppler shift axis was calibrated with ${ }^{57} \mathrm{Fe}$ foil.

\section{ii) Experimental details}

\section{a) Sample Preparation for UV-Vis Spectroscopy:}

Synthesized $\mathrm{Fe}^{\mathrm{III}} \mathrm{TPP}^{1}$ was dissolved in dry degassed THF to prepare $1 \mathrm{mM}$ solution. It was subjected to reduction using a 0.5 eq. ( $20 \mathrm{mM}$ stock solution) of $\mathrm{Na}_{2} \mathrm{~S}$ in dry degassed methanol. ${ }^{2}$ The reduction was monitored using UV-Vis. Pure and dry $\mathrm{SO}_{2}$ gas bubbled in dry degassed THF to prepare a saturated solution of $\mathrm{SO}_{2}$ in THF. 10-80 $\mu \mathrm{L}$ of $\mathrm{SO}_{2}$ saturated THF (0.3-0.5 M) was added to the ferrous porphyrin and the absorption was recorded.

\section{b) Trapping of Sulfur Monoxide:}

A solution of Fe ${ }^{\mathrm{II}} \mathrm{TPP}$ (712 mg, $1.01 \mathrm{~mol}$ ) prepared in dry degassed THF, was bubbled with dry and pure $\mathrm{SO}_{2}$ gas for a minute at $-80^{\circ} \mathrm{C}$. The reaction mixture was then transferred to a reaction vessel containing degassed 2,3-Dimethyl-1,3-butadiene ( $\sim 2 \mathrm{ml}, 10.10 \mathrm{~mol}, 10$-fold excess), the addition was done at $0^{\circ} \mathrm{C}$ and the reaction was allowed to continue for 72 hours under nitrogen atmosphere. In vacuo evaporation of the THF solvent left us with the reaction mixture. The second fraction in column chromatography, which elutes out in Hexane, affords 2,5-dihydro-3,4-dimethylthiophene-1-oxide. The product was identified using GC/MS and IR Spectroscopy.

A control reaction was also set up for the purpose of ascertaining the proper source of Sulfur Monoxide. The control reaction was set up where the reactants are sodium sulphide (reductant). It was bubbled with dry and pure $\mathrm{SO}_{2}$ gas for several minutes and the reaction mixture was transferred to a reaction vessel containing degassed 2,3-Dimethyl-1,3-butadiene ( $\sim 2 \mathrm{ml}, 10.1 \mathrm{~mol})$, the addition was done at $0^{\circ} \mathrm{C}$ and the reaction was allowed to continue for 72 hours under nitrogen atmosphere. The control reaction was analysed using GC/MS and IR Spectroscopy and no sulfoxide could be detected (Fig. S3).

\section{c) Sample Preparation for EPR, Mossbauer and Raman Spectroscopy:}

$\mathrm{Fe}^{\mathrm{III}} \mathrm{TPP}$ was reduced to $\mathrm{Fe}^{\mathrm{II}} \mathrm{TPP}$. In an EPR Tube a $20 \mu \mathrm{L}, 5 \mathrm{mM}$ solution of $\mathrm{Fe}^{\mathrm{II}} \mathrm{TPP}$ was taken and it was injected with an $80 \mu \mathrm{L}$ saturated solution of dry and pure $\mathrm{SO}_{2}$ gas in THF to afford a solution of 1 $\mathrm{mM}$ concentration. The reaction was allowed to progress for 10 minutes before freezing it in liq. $\mathrm{N}_{2}$ for EPR analysis, Mossbauer and resonance Raman analysis. 
Figure S1: Absorption Data of Fe ${ }^{\mathrm{II}} \mathrm{TPP}+\mathrm{SO} 2$ (red), Fe ${ }^{\mathrm{III}} \mathrm{TPP}$ (yellow) and Normalized Difference Spectra (grey).
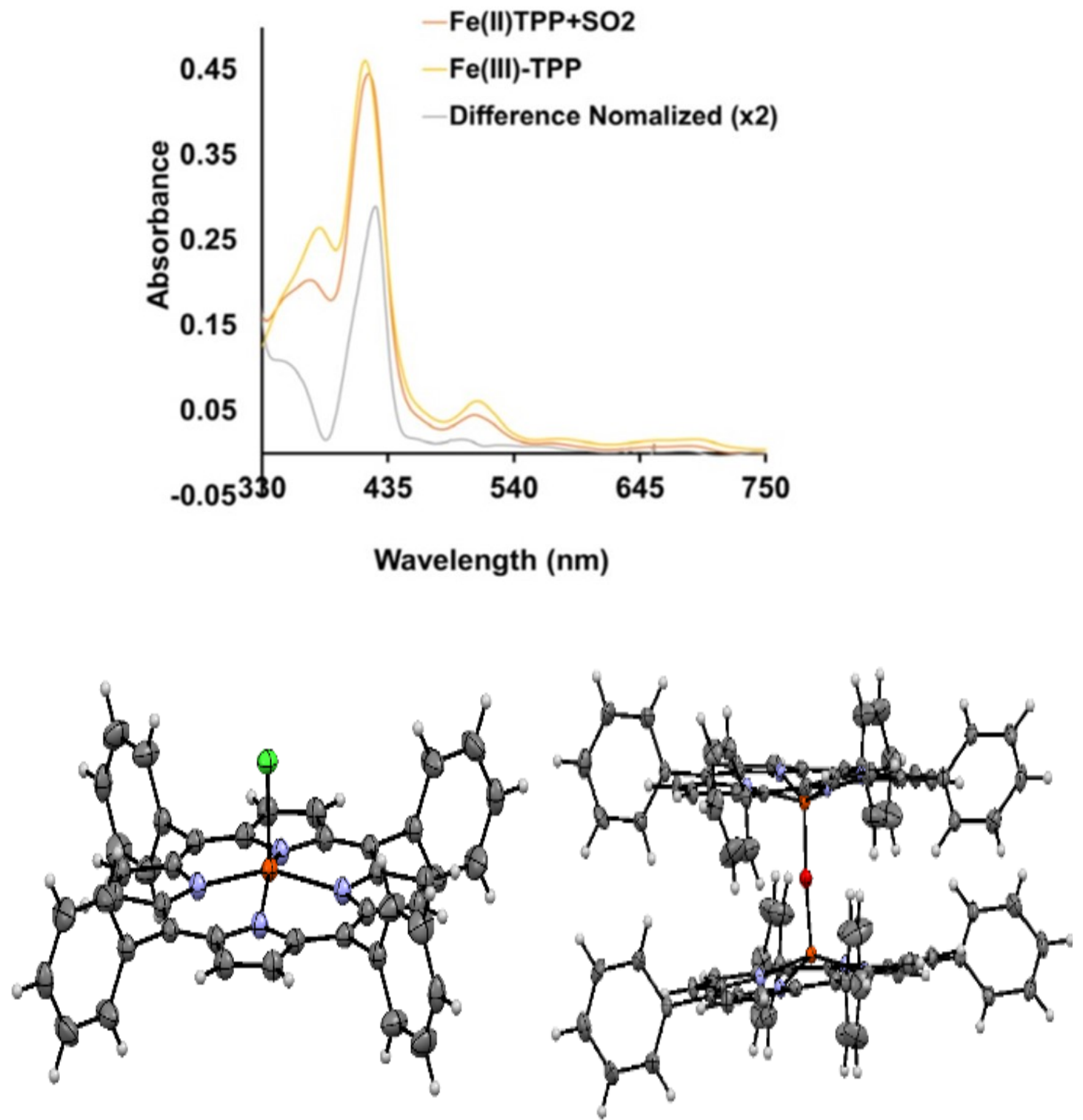

Figure S2. (left) Structure of $\mathrm{Fe}^{\mathrm{III}} \mathrm{TPP}-\mathrm{Cl}$ crystallized from the reaction mixture and (right) ${ }^{3}$ structure of the $\mu$-oxo dimer formed when the reduced FeTPP is exposed to $\mathrm{O}_{2} \cdot{ }^{4}$ Color code: Orange $\rightarrow \mathrm{Fe}$, green $\rightarrow \mathrm{Cl}$, red $\rightarrow \mathrm{O}$, blue $\rightarrow \mathrm{N}$, grey $\rightarrow \mathrm{C}$ and white $\rightarrow \mathrm{H}$ 

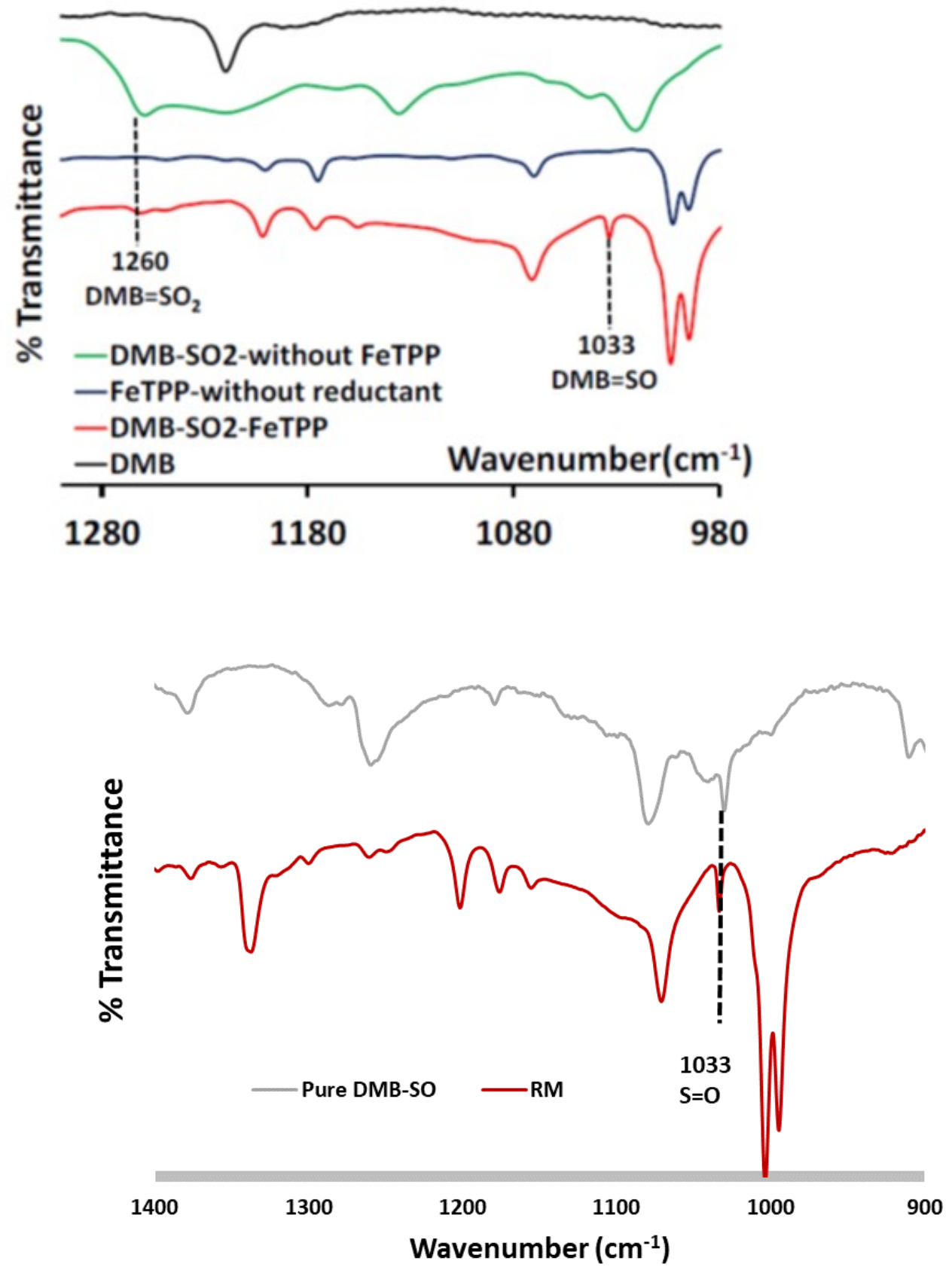

Figure S3. (Top) FTIR data of the reaction mixture (red), control reaction mixture (green), FeTPP without reductant (blue) and DMB (black) and (bottom) FTIR data (liquid sample on ATR crystal) of pure DA adduct of SO and DMB. 

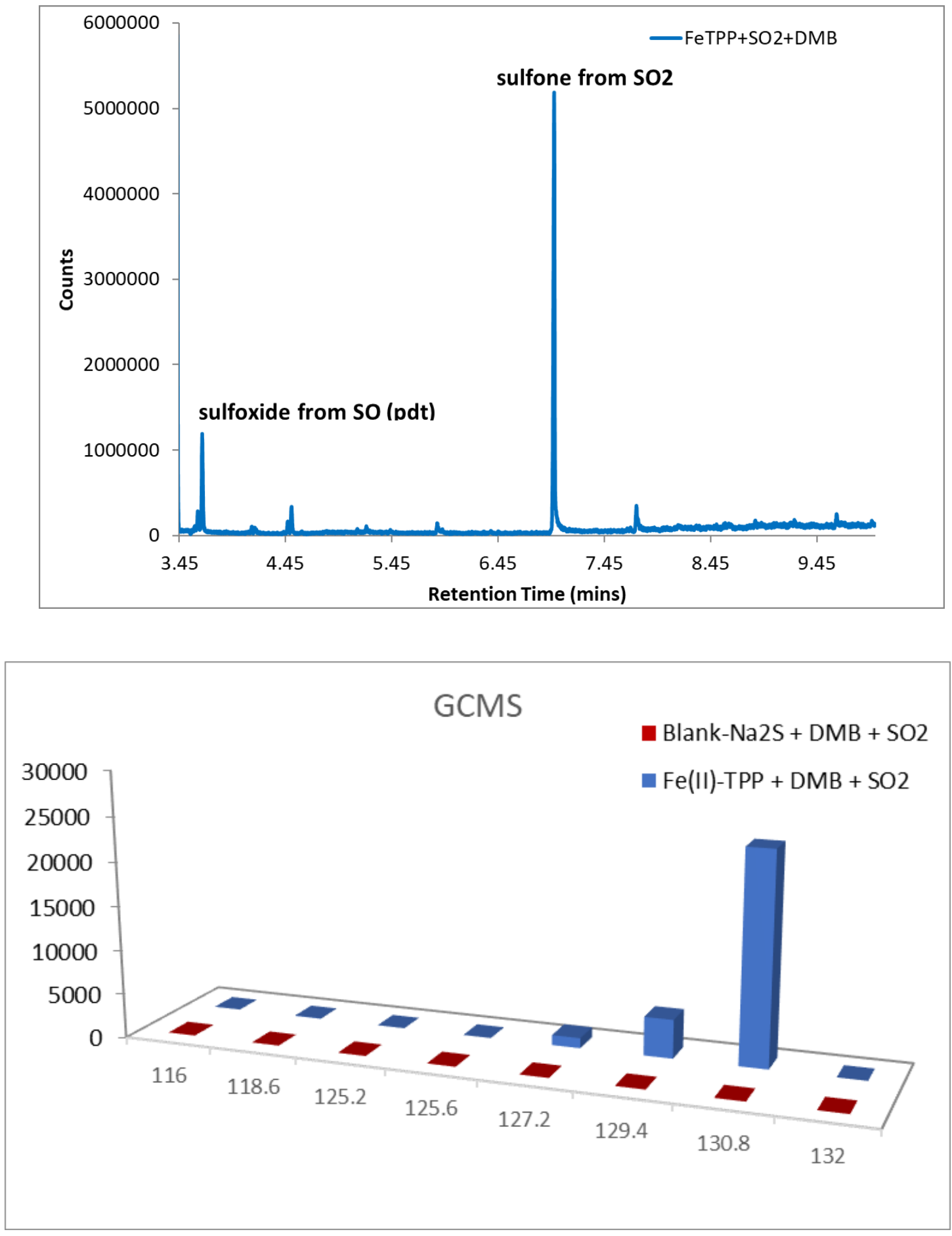

Figure S4. MS data for the reaction mixture in blue showing the DMB-SO at 3.66 mins and that of the control sample without Fe ${ }^{\mathrm{II}} \mathrm{TPP}$ (red). 


\section{References:}

1. Lindsey, J. S.; Schreiman, I. C.; Hsu, H. C.; Kearney, P. C.; Marguerettaz, A. M., Rothemund and Adler-Longo reactions revisited: synthesis of tetraphenylporphyrins under equilibrium conditions. The Journal of Organic Chemistry 1987, 52 (5), 827-836.

2. Mittra, K.; Singha, A.; Dey, A., Mechanism of Reduction of Ferric Porphyrins by Sulfide: Identification of a Low Spin Fe ${ }^{\mathrm{III}}-\mathrm{SH}$ Intermediate. Inorganic Chemistry 2017, 56 (7), 3916-3925.

3. Silver, J.; Marsh, P. J.; Symons, C. R. M.; Svistunenko, D. A.; Frampton, C. S.; Fern, G. R.; Crystal Structure of Bis(4-methylimidazole)tetraphenylporphyrinatoiron(III) Chloride and Related Compounds. Correlation of Ground State with Fe-N Bond Lengths Inorganic Chemistry 2000, 39 (13), 2874-2881.

4. Hoffman, A. B.; Collins, D. M.; Day, V. W.; Fleischer, B. E.; Srivastava, S. T.; Hoard, J. L.; The crystal structure and Molecular spectroscopy of $\mu$-Oxo-bis [ $\alpha, \beta, \gamma, \delta$-tetraphenylporphyrin (III)] Journal of the American Chemical Society 1972, 94 (10), 3620-3626. 